\title{
The ANalysis of ENTRepreneurial Activity IN the Area of Brod-Posavina County for the Perlod From the Year 2014 TO THE Year 2018
}

\begin{abstract}
:
The main objective of this paper is to determine total investments by activities in Brod-Posavina County, revenues and expenditures level, number of entrepreneurs by activities, including the achieved financial results of entrepreneurs of the Brod-Posavina County over the past five vears.

During research of facts and possibilities that currently exist, the following research methods are used in a different combination: historical method, the method of analysis and synthesis, classification, description method and generalization.
\end{abstract}

\section{Keywords:}

Entrepreneurs; investments; financial results; Brod-Posavina County

\section{Author's data:}

1'Ivona, Blažević, mag. oec., viši predavač, Veleučilište u Slavonskom Brodu, Dr. Mile Budaka 1, Slavonski Brod, ivona.blazevic@vusb.hr

${ }^{2}$ dr. Sc. Andreja Katolik Kovačevič, viši predavač, Veleučilište u Slavonskom Brodu, Dr. Mile Budaka1, Slavonski Brod, andreja.katolik.kovacevic@vusb.hr

${ }^{3}$ Mirko Cobovič, univ. spec. oec., viši predavač, Veleučilište u Slavonskom Brodu, Dr. Mile Budaka 1, Slavonski Brod, mirko.cobovic@vusb.hr

International Journal - VALLIS AUREA • Volume 6 • Number 2 • Croatia, December 2020

UDK 658.1"2014/2018"(497.54); DOI 10.2507/IJVA.6.2.4.73 


\section{Introduction}

Entrepreneurship has historically been one of the most widely investigated topics in economic literature [1]. Traditionally related with the creation and growth of economic activities [2], entrepreneurship has been studied with multiple facets over the past years. It has been identified as one of the main elements of economic growth and GDP increases [3] as a factor fostering the economical sustainability of developing countries [4] as a factor influencing regional development through jobs creation [5] as one of individual responses to unemployment [6] in times of economic recession [7] as a driver of innovation and new product creation [8].

Croatia is at the top of the EU in terms of entrepreneurial activity, but this hidden component of the country's entrepreneurial capacity is not well recognized by employers. With incentive compensation programs within the company, this entrepreneurial activity of the employees would very effectively contribute to the creation of new products, and thus to a better utilization of invested in the technological equipment of the company and competitiveness.

There are on average 5 times more people entering the EU for entrepreneurial activity because of the perceived opportunity, and in Croatia, there are only 1.9 times more such entrepreneurs. At the same time, Croatia in the period 2016-2018 keeps the density of "adult" enterprises (number of "adult" enterprises per 100 adult population] at 4.2\%, which is only 62\% of the EU average. Such a low level of presence of "adult" enterprises is a long- standing characteristic of the Croatian economy, which continues to point to the low basis of generating new value. Perhaps the reason is that one of the basic characteristics of the Croatian economy is the great difference in the development of individual regions - counties. The most intensive growth of entrepreneurial activity is shown by Dalmatia, and Istria, Primorje and Gorski Kotar. The biggest decline in entrepreneurial activity is in Lika and Banovina, where the level of entrepreneurial activity is the lowest, but at the same time, the motivational index is improving. Throughout the observed period, the lowest positive perception of the situation is in the regions of Lika and Banovina and Slavonia and Baranja, and the highest in Istria, the Primorje and Gorski Kotar and in Dalmatia. (http://WWW. novilist.hr/Vijesti/Gospodarstvo/GE M-istrazivanje-Najintenzivniji-rast-poduzetnickeaktivnosti-pokazuju-Dalmacija-Istra-Primorje-iGorski-Kotar]

For 2018, 131,117 annual financial statements of corporate income taxpayers without banks, insurance companies and other financial institutions were collected and processed in the Register of Financial Agency, based on which the data in this paper were processed. Part of the register is the data and documentation of entrepreneurs from the Brod-posavina county on the basis of which the analysis was made. (Brodposavina county, Administrative Department for the Economy]

Methods of analysis, synthesis and compilation and statistical method of data processing were used in the paper. Data were processed using the Microsoft Excel and statsoft statistica software 
tools. The most important shortcomings of the statistical method used in this papaer are quantitative, numerical definiteness of phenomena and the question of possibility cognitions of the general on the basis of the individual and the special.

\section{Entrepreneurial activity of the Brod-posavina county}

In the Brod-posavina county in 2018, according to the number of annual financial statements processed, 2,042 were headquartered, employing 18,398 , which is a $6.4 \%$ increase in the number of employees. In 2018, county entrepreneurs generated total revenues of HRK 9.8 billion $[8.6 \%$ more than in 2017), total expenditures of HRK 9.5 billion (10.4\% more), profit periods in the amount of HRK 434.1 million (1.1\% less), Ioss of the period of HRK 271.9 million (87.9\% more) and net profit of HRK 162.2 million (44.9\% less). Gross investment in new fixed assets increased by $55.6 \%$ over the previous year. Imports increased by $13.3 \%$ and exports by $6.7 \%$, with a trade surplus of HRK 1.7 billion. The average monthly net earning was HRK 4,925 , which is $3.7 \%$ more than in 2017. (County of Brod-Posavina, Administrative Department for the Economy]

\begin{tabular}{|c|c|c|c|c|}
\hline \multirow{2}{*}{$\begin{array}{l}\text { Name of the } \\
\text { city I } \\
\text { municipality }\end{array}$} & \multicolumn{2}{|c|}{$\begin{array}{l}\text { Number of } \\
\text { entrepreneurs }\end{array}$} & \multicolumn{2}{|c|}{$\begin{array}{l}\text { Number of } \\
\text { employees }\end{array}$} \\
\hline & Number & $\begin{array}{l}\text { Rank in } \\
\text { Croatia }\end{array}$ & Number & $\begin{array}{l}\text { Rank } \\
\text { in } \\
\text { Croatia }\end{array}$ \\
\hline $\begin{array}{l}\text { Slavonski } \\
\text { Brod* }\end{array}$ & 1.157 & 15 & 12.040 & 10 \\
\hline $\begin{array}{l}\text { Nova } \\
\text { Gradiška* }\end{array}$ & 249 & 67 & 2.051 & 58 \\
\hline Oriovac** & 51 & 252 & 637 & 149 \\
\hline $\begin{array}{l}\text { Gornja } \\
\text { Vrba*** }\end{array}$ & 36 & 311 & 504 & 175 \\
\hline \multirow[t]{3}{*}{ Oprisavci** } & 28 & 360 & 405 & 198 \\
\hline & \multicolumn{2}{|c|}{ Total income } & \multicolumn{2}{|c|}{ Net profit / loss } \\
\hline & Number & $\begin{array}{l}\text { Rank in } \\
\text { Croatia }\end{array}$ & Number & $\begin{array}{r}\text { Rank } \\
\text { in } \\
\text { Croatia }\end{array}$ \\
\hline $\begin{array}{l}\text { Slavonski } \\
\text { Brod* }\end{array}$ & 5.741.197 & 15 & 218.592 & 24 \\
\hline $\begin{array}{l}\text { Nova } \\
\text { Gradiška* }\end{array}$ & 1.642 .397 & 49 & 84.787 & 53 \\
\hline Oriovac** & 365.726 & 148 & 29.892 & 117 \\
\hline $\begin{array}{l}\text { Gornja } \\
\text { Vrba** }\end{array}$ & 348.628 & 153 & 3.182 & 382 \\
\hline Oprisavci** & 285.083 & 173 & 20.316 & 155 \\
\hline
\end{tabular}

Table 1. Toplist of 5/argest cities*/municipalities ${ }^{* *}$ of Brod-posavina county by criterion of total entrepreneur income in 2018 thousand kn

Source: Register of Annual Financial statements

In the ranking of 28 cities and municipalities of Brod-posavina county, Slavonski Brod entrepreneurs are the first by number of entrepreneurs (1,157), by number of employees (12,040), by total revenue (HRK 5.7 billion), by period profit (HRK 218.6 million]. J and after the loss of the period (HRK 214.8 million), while the first entrepreneurs of Nova Gradiška [HRK 58.9 million) made net profit. The Brod-posavina county is in 13th place in comparison with other counties in terms of the number of employees with entrepreneurs. In terms of total income and net profit, it is in 16th place, and in terms of number of 
entrepreneurs and labour productivity indicator, measured by the ratio of total income and number of employees, it is in 17th place. According to the labour productivity indicator, measured by the ratio of net income to the number of employees, it is ranked 18th, and in economic efficiency it ranks 19th among all counties.

\section{The analysis of entrepreneurial} activity in the area of Brod-posavina county

In this chapter will be analyzed entrepreneurial activity in the area of Brod-posavina county for a period of five years, from the year 2014 to the year 2018.

\begin{tabular}{|c|c|l|}
\hline $\begin{array}{c}\text { N } \\
\text { O. }\end{array}$ & $\begin{array}{c}\text { Sym } \\
\text { bol }\end{array}$ & \multicolumn{1}{|c|}{ Activity } \\
\hline 1 & A & Agriculture, forestry and fishing \\
\hline 2 & B & Mining and quarrying \\
\hline 3 & C & Manufacturing \\
\hline 4 & D & $\begin{array}{l}\text { Electricity, gas, steam and air conditioning } \\
\text { supply }\end{array}$ \\
\hline 5 & E & $\begin{array}{l}\text { Water supply; sewerage, waste management and } \\
\text { remediation activities }\end{array}$ \\
\hline 6 & F & Construction \\
\hline 7 & G & Wholesale and retail trade \\
\hline 8 & H & Transportation and storage \\
\hline 9 & I & Accommodation and food service activities \\
\hline 10 & J & Information and communication \\
\hline 11 & K & Financial and insurance activities \\
\hline 12 & L & Real estate activities \\
\hline 13 & M & Professional, scientific and technical activities \\
\hline 14 & N & Administrative and support service activities \\
\hline 15 & 0 & $\begin{array}{l}\text { Public administration and defence; compulsory } \\
\text { social security }\end{array}$ \\
\hline 16 & P & Education \\
\hline 17 & Q & Human health and social work activities \\
\hline 18 & R & Arts, entertainment and recreation \\
\hline 19 & S & Other service activities \\
\hline 20 & I & Activities of households as employers \\
\hline 21 & U & $\begin{array}{l}\text { Activities of extraterritorial organisations and } \\
\text { bodies }\end{array}$ \\
\hline
\end{tabular}

Table 2. Activities division according to NKD 2007 Source: Croatian bureau of statistics

Table 2. shows activities divided according to NKD 2007. Based on this division, in the following tables will be analyzed the entrepreneurial activity in the Brod-posavina county.

\begin{tabular}{|c|c|c|c|c|c|}
\hline \multirow{2}{*}{ Activity/Year } & \multicolumn{5}{|c|}{ Number of entrepreneurs } \\
\hline & 2014 & 2015 & 2016 & 2017 & 2018 \\
\hline A & 72 & 77 & 75 & 72 & 80 \\
\hline C & 281 & 298 & 321 & 335 & 338 \\
\hline$F$ & 190 & 229 & 231 & 235 & 263 \\
\hline$G$ & 332 & 358 & 367 & 356 & 382 \\
\hline$H$ & 71 & 80 & 82 & 88 & 94 \\
\hline I & 61 & 87 & 103 & 104 & 118 \\
\hline $\mathrm{J}$ & 53 & 59 & 62 & 69 & 73 \\
\hline$M$ & 195 & 215 & 228 & 226 & 249 \\
\hline N & 21 & 29 & 31 & 36 & 42 \\
\hline$P$ & 12 & 25 & 20 & 19 & 28 \\
\hline 0 & 16 & 29 & 17 & 16 & 29 \\
\hline \multirow[t]{3}{*}{$\mathrm{BPC}$} & 1427 & 1627 & 1679 & 1695 & 1842 \\
\hline & \multicolumn{5}{|c|}{ Number of employees } \\
\hline & 2014 & 2015 & 2016 & 2017 & 2018 \\
\hline A & 473 & 546 & 550 & 573 & 737 \\
\hline C & 7326 & 7284 & 7654 & 7886 & 8621 \\
\hline $\mathrm{F}$ & 1782 & 1918 & 2068 & 2043 & 2459 \\
\hline$G$ & 1326 & 1438 & 1353 & 1408 & 1585 \\
\hline $\mathrm{H}$ & 225 & 274 & 345 & 358 & 355 \\
\hline 1 & 260 & 315 & 406 & 404 & 493 \\
\hline$J$ & 294 & 337 & 364 & 450 & 492 \\
\hline$M$ & 705 & 966 & 1083 & 980 & 985 \\
\hline $\mathrm{N}$ & 100 & 171 & 165 & 210 & 212 \\
\hline$P$ & 40 & 93 & 86 & 87 & 139 \\
\hline 0 & 49 & 140 & 40 & 50 & 176 \\
\hline $\mathrm{BPC}$ & 13451 & 14416 & 15051 & 15407 & 17301 \\
\hline
\end{tabular}

Table 3. Number of entrepreneurs and employees

Source: Authors according to data from croatian Chamber of Economy

According to Table 3 , the largest number of entrepreneurs are in the following activities: 
Manufacturing, Construction, Wholesale and retail trade and Professional, scientific and technical activities. It is interesting that entrepreneurship is not developed in activities such as: Public administration and defence; compulsory social security, Activities of households as employers and Activities of extraterritorial organisations and bodies. In the last observed year, the number of entrepreneurs by the activities is the highest.

The largest number of employees is in the activity of Manufacturing. If Public administration and defence; compulsory social security, Activities of households as employers and Activities of extraterritorial organisations and bodies are excluded, the smallest number of employees is in Financial and insurance activities, Real estate activities and Arts, entertainment and recreation activity. In most activities, the number of employees increases through the vears.

\begin{tabular}{|c|r|r|r|r|r|r|r|r|r|r|}
\hline \multirow{2}{*}{ Activity } & \multicolumn{9}{|c|}{ Number of entrepreneurs } & \multicolumn{5}{|c|}{ Number of emplovees } \\
\cline { 2 - 12 } & Mean & \multicolumn{1}{|c|}{ Min } & Max & Variance & Std. Dev. & Mean & Min & Max & Variance & Std.Dev. \\
\hline A & 75,2 & 72 & 80 & 11,7 & 3,421 & 575,8 & 473 & 737 & 9529 & 97,615 \\
\hline C & 314,6 & 281 & 338 & 602,3 & 24,542 & 7754,2 & 7284 & 8621 & 295799 & 543,874 \\
\hline F & 229,6 & 190 & 263 & 678,8 & 26,054 & 2054 & 1782 & 2459 & 64206 & 253,388 \\
\hline G & 359 & 332 & 382 & 333 & 18,248 & 1422 & 1326 & 1585 & 10250 & 101,24 \\
\hline H & 83 & 71 & 94 & 75 & 8,66 & 311,4 & 225 & 358 & 3516 & 59,298 \\
\hline I & 94,6 & 61 & 118 & 473,3 & 21,755 & 375,6 & 260 & 493 & 8137 & 90,207 \\
\hline J & 63,2 & 53 & 73 & 63,2 & 7,95 & 387,4 & 294 & 492 & 6668 & 81,657 \\
\hline M & 222,6 & 195 & 249 & 389,3 & 19,731 & 943,8 & 705 & 1083 & 19976 & 141,335 \\
\hline N & 31,8 & 21 & 42 & 61,7 & 7,855 & 171,6 & 100 & 212 & 2069 & 45,49 \\
\hline P & 20,8 & 12 & 28 & 37,7 & 6,14 & 89 & 40 & 139 & 1233 & 35,107 \\
\hline O & 21,4 & 16 & 29 & 48,3 & 6,95 & 91 & 40 & 176 & 3918 & 62,594 \\
\hline BPC & 1654 & 1427 & 1842 & 22477 & 149,923 & 15125,2 & 13451 & 17301 & 2031233 & 1425,213 \\
\hline
\end{tabular}

Iable 4. Number of entrepreneurs and employees descriptive statistics

Source: Authors according to Table 3

According to the data in the table, for the observed period 2014-2018, the average number of entrepreneurs in Brod-posavina county is 1654. In 5 years, the increase is $20 \%$. The largest representation of entrepreneurs is in the Wholesale and retail trade, Manufacturing, Construction and Professional, scientific and technical activities. Regarding to changes in the number of entrepreneurs by activities, i.e. variance, the following activity are significant: Construction, Manufacturing, Accommodation and food service activities, Professional, scientific and technical activities and Wholesale and retail trade.

In Brod-posavina County, the average number of employees per year in 5 year period is 15125. Most employees are in manufacturing, over 50\%. The biggest changes in the number of employees are in the activity manufacturing and construction. 


\begin{tabular}{|c|r|r|r|r|r|}
\hline Activity/Year & \multicolumn{1}{|c|}{2014} & \multicolumn{1}{c|}{2015} & \multicolumn{1}{c|}{2016} & \multicolumn{1}{c|}{2017} & \multicolumn{1}{c|}{2018} \\
\hline A & 555741019 & 529468467 & 696378605 & 595015505 & 796966994 \\
\hline C & 2915157738 & 3365800630 & 3333175612 & 3992219607 & 4300907139 \\
\hline F & 744176362 & 1129304278 & 917241360 & 621777082 & 980999902 \\
\hline G & 1004776242 & 1062611543 & 1024639253 & 1130448238 & 1577793769 \\
\hline H & 98457099 & 124777390 & 158865843 & 1859334655 & 142079998 \\
\hline I & 47780127 & 61494606 & 74666289 & 80063548 & 96590274 \\
\hline J & 51930954 & 55626556 & 66497679 & 79952046 & 104055875 \\
\hline M & 341474851 & 413283641 & 6933933697 & 425111861 & 434990799 \\
\hline N & 22930387 & 32240543 & 34344961 & 43356151 & 45915968 \\
\hline P & 10719438 & 22686523 & 15999641 & 18655562 & 28978966 \\
\hline Q & 4948168 & 13569505 & 4442651 & 4203634 & 20123263 \\
\hline BPC & 6220832981 & 7252968454 & 7455227473 & 7596902467 & 8997968260 \\
\hline
\end{tabular}

\section{Table 5. Total income in kn}

Source: Authors according to data from Croatian Chamber of Economy

The table shows the total income of the entrepreneurial activities over a period of 5 years. By far the largest income have the following activities: Manufacturing and Wholesale and retail trade. If the initial and final year of the reference period for Manufacturing activity are compared, the income has increased by 47,54\%.

\begin{tabular}{|c|c|c|c|c|c|}
\hline Activity & Mean & Minimum & Maximum & Variance & Std.Dev. \\
\hline$A$ & 634714118 & 529468467 & 796966994 & 12254470505361482 & 110699912 \\
\hline $\mathrm{F}$ & 880179797 & 621177082 & 1129304278 & 40214430611725960 & 200535360 \\
\hline G & 1160053809 & 1004776242 & 1577793769 & 56831596002092256 & 238393783 \\
\hline$H$ & 142022759 & 98457099 & 185933465 & 1101803084883594 & 33193419 \\
\hline I & 72118969 & 47780127 & 96590274 & 343426565532350 & 18531772 \\
\hline$J$ & 71612622 & 51930954 & 104055875 & 447798915296404 & 21161260 \\
\hline M & 461758970 & 341474851 & 693933697 & 18195694059883016 & 134891416 \\
\hline$N$ & 35757602 & 22930387 & 45915968 & 84958262488986 & 9217281 \\
\hline$P$ & 19408026 & 10719438 & 28978966 & 47506571718969 & 6892501 \\
\hline 0 & 9457444 & 4203634 & 20123263 & 50938244750402 & 7137103 \\
\hline $\mathrm{BPC}$ & 7504779927 & 6220832981 & 8997968260 & 988120545989487490 & 994042527 \\
\hline
\end{tabular}

Table 6. Total income, descriptive statistics in kn

Source: Authors according to Table 5

The average income of entrepreneurial activities in the observed period was HRK 7.5 billion, average per year. The largest contribution to income is made by Manufacturing, Wholesale and retail trade, where variance is highest. Other activities, in total, are below 40\% of income. 


\begin{tabular}{|c|r|r|r|r|r|}
\hline Activity/Year & \multicolumn{1}{|c|}{2014} & \multicolumn{1}{c|}{2015} & \multicolumn{1}{c|}{2016} & \multicolumn{1}{c|}{2017} & \multicolumn{1}{c|}{2018} \\
\hline A & 554475927 & 523616099 & 686988072 & 579379548 & 779349373 \\
\hline C & 2931414693 & 3404868352 & 3242546215 & 3775679009 & 4109022084 \\
\hline F & 791129547 & 1078911661 & 906987061 & 617253895 & 962627008 \\
\hline G & 989146853 & 1048615487 & 1003645325 & 11185255945 & 1548532430 \\
\hline H & 99001745 & 121608539 & 154603234 & 176681338 & 136021409 \\
\hline I & 45414708 & 58160522 & 70006392 & 80730338 & 93629427 \\
\hline J & 48787596 & 52047172 & 61772314 & 74992785 & 96536732 \\
\hline M & 333104591 & 41806000 & 707353098 & 442706222 & 570687318 \\
\hline N & 22134076 & 30709777 & 33670275 & 42848225 & 45297150 \\
\hline P & 8677077 & 19631864 & 14851762 & 15636079 & 25161878 \\
\hline Q & 5045467 & 12921234 & 4325370 & 4504463 & 19158886 \\
\hline BPC & 6247191114 & 7229813545 & 7317854000 & 7323931459 & 8813829397 \\
\hline
\end{tabular}

\section{Table 7. Total expenditures in kn}

Source: Authors according to data from Croatian Chamber of Economy

As revenues were highest in Manufacturing and Wholesale and retail trade, as expected, expenditures are also the largest in these activities as it is which is evident from the Table 7. Comparing 2014 and 2018 year, in Manufacturing activity, expenditures have increased by 40,77\%. Comparing the same years for activity Wholesale and retail trade, expenditures have increased by $56,55 \%$. The minimum expenditure was recorded in Financial and insurance activities, in 2018. it amounted 2.009.660 thousand kuna's, which is 1,26\% more compared to 2014 year.

\begin{tabular}{|c|r|r|r|r|r|}
\hline Activity & \multicolumn{1}{|c|}{ Mean } & \multicolumn{1}{c|}{ Minimum } & \multicolumn{1}{c|}{ Maximum } & \multicolumn{1}{c|}{ Variance } & \multicolumn{1}{c|}{ Std.Dev. } \\
\hline A & 624841804 & 523616099 & 779349373 & 11235857800588322 & 105999330 \\
\hline C & 3492706071 & 2931414693 & 4109022084 & 2113156352426992670 & 459690804 \\
\hline F & 871381834 & 617253895 & 1078911661 & 30920870502944960 & 175843312 \\
\hline G & 1141693208 & 989146853 & 1548532430 & 54261486300899512 & 232940950 \\
\hline H & 137583253 & 99001745 & 176681338 & 891125901880946 & 29851732 \\
\hline I & 69588277 & 45414708 & 93629427 & 354313064835308 & 18823205 \\
\hline J & 66827320 & 48787596 & 96536732 & 379690370652521 & 19485645 \\
\hline M & 494382246 & 333104591 & 707353098 & 21421256588779680 & 146360024 \\
\hline N & 34931901 & 22134076 & 45297150 & 88327232117713 & 9398257 \\
\hline P & 16791732 & 8677077 & 25161878 & 37268084266269 & 6104759 \\
\hline Q & 9191084 & 4325370 & 19158886 & 44024206292958 & 6635074 \\
\hline BPC & 7386523903 & 6247191114 & 8813829397 & 842179200055378430 & 917669832 \\
\hline
\end{tabular}

Table 8. Total expenditures description statistics in kn

Source: Authors according to Table 7

International Journal - VALLIS AUREA • Volume 6 • Number 2 • Croatia, December 2020 UDK658.1"2014/2018"(497.54); 001 10.2507/JJVA.6.2.4.73 
The average of total expenditures of entrepreneurial activities in the observed period amounted to HRK 7.4 billion. The largest contribution to total expenditures is made by Manufacturing, Wholesale and retail trade. Variances for mentioned activities are highest. Other entrepreneurial activities make less than 40\% of total expenditures in Brod-posavina county. By comparing data of income and total expenditures, it is clear that entrepreneurs in Brod-posavina county realized total profits of HRK O.1 billion average per year.

\begin{tabular}{|r|r|r|r|r|r|}
\hline Activity/Year & \multicolumn{1}{|c|}{2014} & \multicolumn{1}{|c|}{2015} & \multicolumn{1}{c|}{2016} & \multicolumn{1}{c|}{2017} & \multicolumn{1}{c|}{2018} \\
\hline A & 116986666 & 12999983 & 6947206 & 3628219 & 5898324 \\
\hline C & 146578462 & 227308053 & 182080484 & 119050248 & 199080581 \\
\hline F & 7859602 & 22487898 & 16537305 & 10137665 & 9194072 \\
\hline G & 5702528 & 7951352 & 7263657 & 2531886 & 6174817 \\
\hline H & 7044338 & 3955762 & 8734268 & 2635852 & 5133575 \\
\hline I & 5726929 & 2641150 & 5223557 & 148946 & 513326 \\
\hline J & 900865 & 469182 & 54001 & 145319 & 371169 \\
\hline M & 55987287 & 73173055 & 60071745 & 4848874 & 3253595 \\
\hline N & 153037 & 217662 & 75211 & 1143818 & 103098 \\
\hline P & 208960 & 543088 & 1151140 & 17227 & 762543 \\
\hline O & 71081 & 133567 & 21448 & 15000 & 283244 \\
\hline BPC & 600951907 & 666287408 & 371002085 & 181848973 & 270670156 \\
\hline
\end{tabular}

\section{Tableg. Investments in kn}

Source: Authors according to data from croatian Chamber of Economy

According to Table 9 . investments were not recorded in the penultimate and last year of the observed period for activity Mining and quarrying, and in the last year for the Real estate activities. Investments were highest in the following activities; Manufacturing, Water supply; sewerage, waste management and remediation activities, Construction and Wholesale and retail trade. The largest investments were recorded in Manufacturing, in 2018. it amounted 199.080 .581 thousand kuna's, which is 3.124,07\% more compared to Wholesale and retail trade in the same vear.

\begin{tabular}{|c|r|r|r|r|r|}
\hline Activity & \multicolumn{1}{|c|}{ Mean } & \multicolumn{1}{c|}{ Minimum } & \multicolumn{1}{c|}{ Maximum } & \multicolumn{1}{c|}{ Variance } & \multicolumn{1}{c|}{ Std.Dev. } \\
\hline A & 8234480 & 3628219 & 12999983 & 15760735773284 & 3969979 \\
\hline C & 174819566 & 119050248 & 227308053 & 1826033957976515 & 42732119 \\
\hline F & 13243308 & 7859602 & 22487898 & 37834620356422 & 6150985 \\
\hline G & 5924848 & 2531886 & 7951352 & 4380807454325 & 2093038 \\
\hline H & 5500759 & 2635852 & 8734268 & 5891937130209 & 2427331 \\
\hline I & 2850782 & 148946 & 5726929 & 6677461666122 & 2584078 \\
\hline J & 388107 & 54001 & 900865 & 110088412553 & 331796 \\
\hline M & 39466911 & 3253595 & 73173055 & 1085849723036723 & 32952234 \\
\hline N & 338565 & 75211 & 1143818 & 205567651402 & 453396 \\
\hline
\end{tabular}




\begin{tabular}{|c|r|r|r|r|r|}
\hline $\mathrm{P}$ & 536592 & 17227 & 1151140 & 201462006842 & 448845 \\
\hline $\mathrm{Q}$ & 104868 & 15000 & 283244 & 12204586293 & 110474 \\
\hline BPC & 418152106 & 181848973 & 666287408 & 43700029016497368 & 209045519 \\
\hline
\end{tabular}

Table 10. Investments description statistics in $\mathrm{kn}$

source: Authors according to Table $g$

In terms of investment, Manufacturing and Water supply, sewerage, waste management and remediation activities are most represented. Other businesses entities are making $30 \%$ of total investments. The largest variances are in the activities of Water supply; sewerage, waste management and remediation activities. The reason for this is the contracted project funded by the EU fund.

\section{Comparison of variables in the domain of entrepreneurial activity for the Brod-} posavina county

In this chapter, the variables that were analyzed separately in the previous chapter will be compared, also for a period of five years, from the year 2014 to the year 2018.

Figure 1. shows a comparison between number of entrepreneurs and number of emplovees of Brod-posavina county from the year 2014 to the year 2018. through all activities.

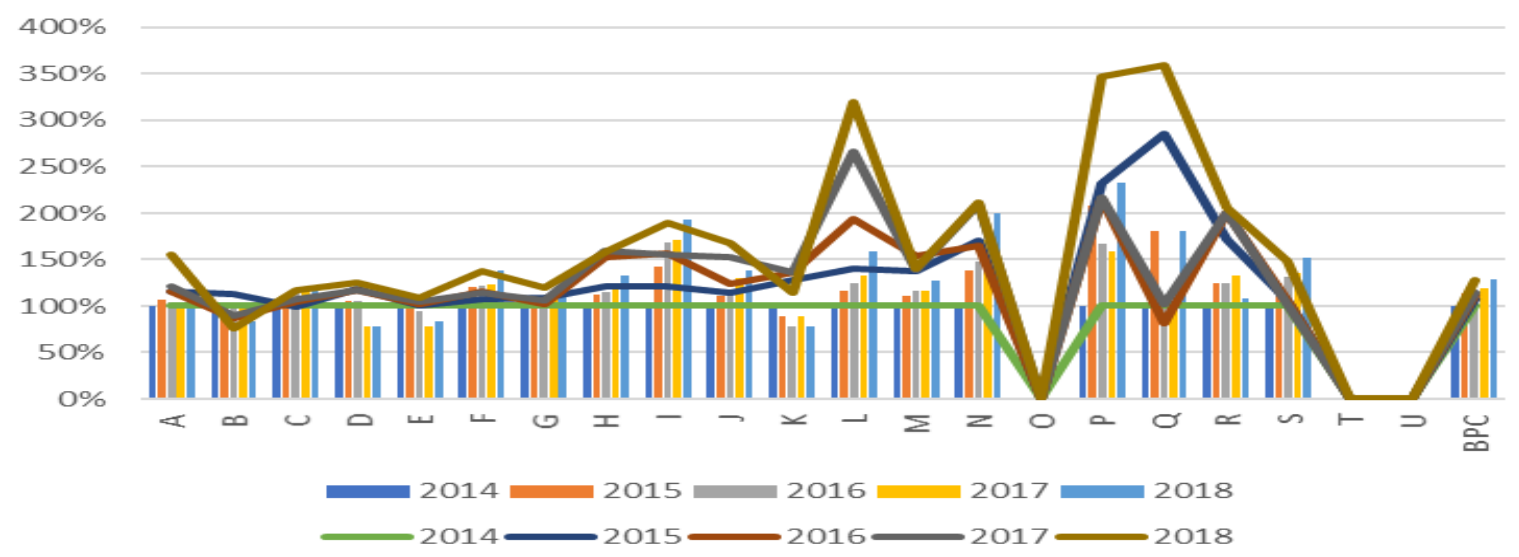

Figure 1. Comparison between number of entrepreneurs and number of employees of Brod-posavina county from the vear 2014 to the vear 2018. through all activities

Source: Authors according to Table 3and Table 5

The Figure 1. shows the relationship between the changes of number of entrepreneurs and number of employees. The Figure1. shows matches in most activities. Inequalities are seen in the number of changes in the number of employees in activities: Real estate activities, Human health and social work activities; compulsory social security and education.

International Journal - VALLIS AUREA • Volume 6 • Number 2 • Croatia, December 2020 UDK 658.1"2014/2018"(497.54); DOI 10.2507/IJVA.6.2.4.73 
Next figure (Figure 2.] shows a comparison between number of entrepreneurs and total income from the year 2014 to the year 2018. through all activities.

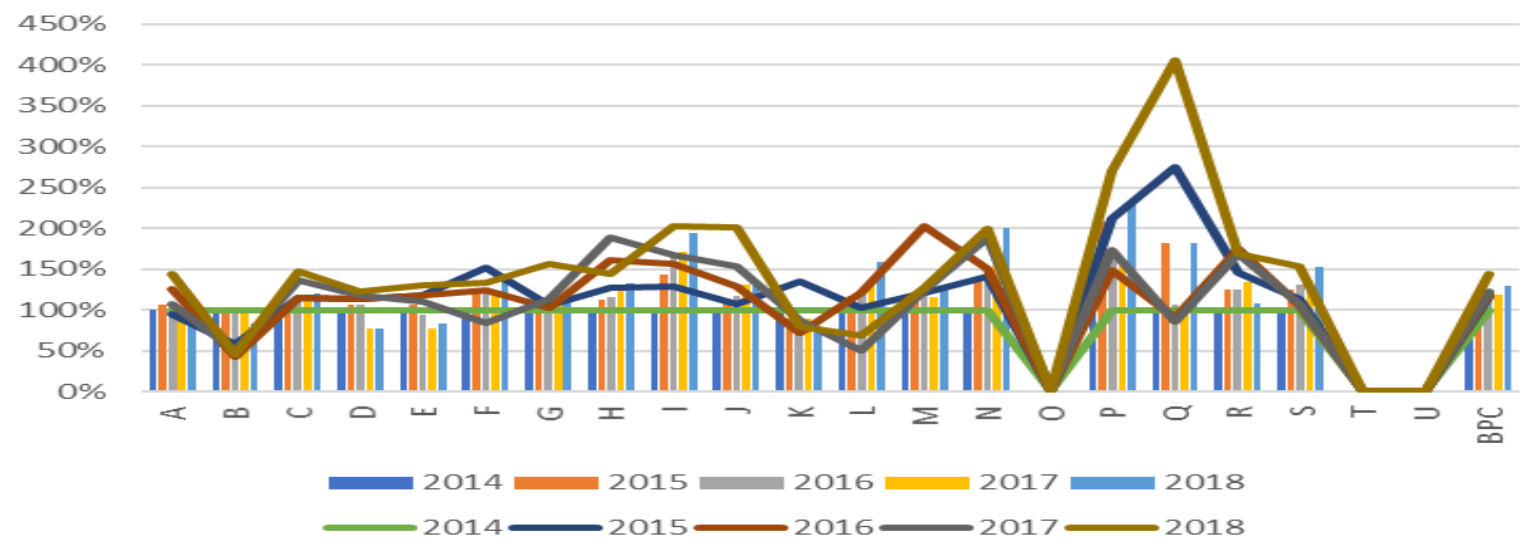

Figure 2. Comparison between number of entrepreneurs and total income from the year 2014 to the year 2018. through all activities

Source: Authors according to Table 3and Table 7

The Figure 2. shows relationships of number of entrepreneurs and total income. The figure shows matches in most activities. Inequalities are seen in following activities: Professional, scientific and technical activities, Public administration and defense; compulsory social security and education.

Figure 3. shows a comparison between number of entrepreneurs and total expenditures from the year 2014 to the vear 2018. through all activities.

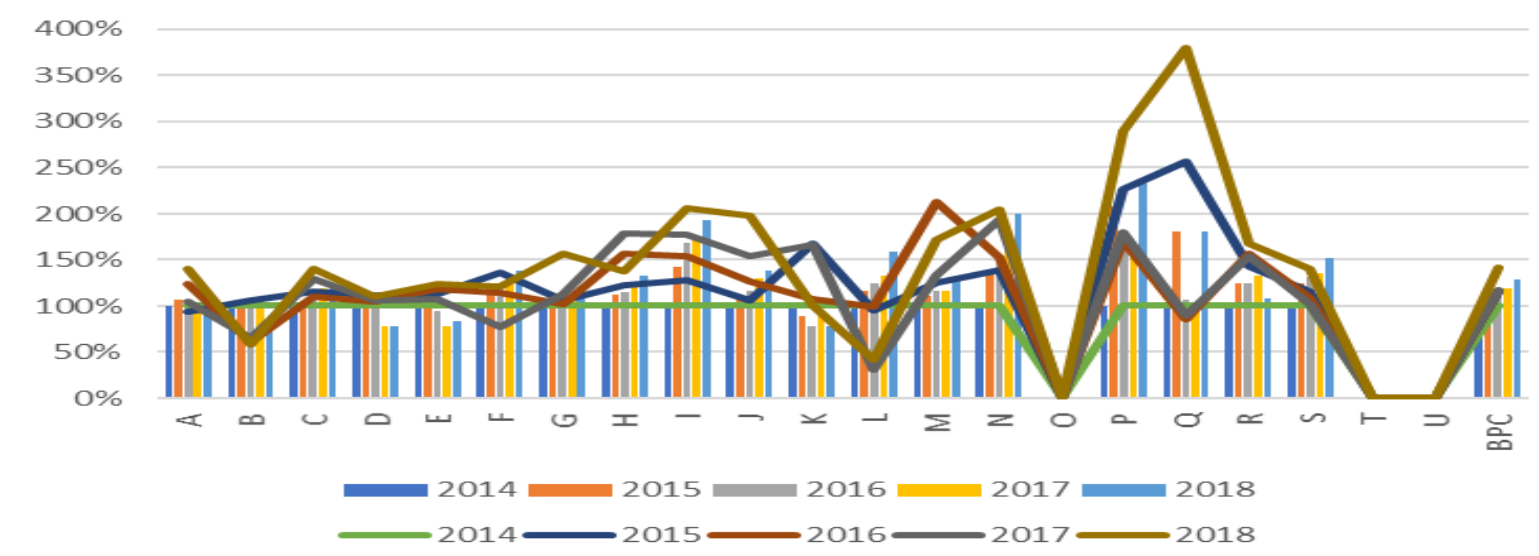

Figure 3. Comparison between number of entrepreneurs and total expenditures from the year 2014 to the year 2018. through all activities

Source: Authors according to Table 3and Table $g$ 
The Figure 3 . shows relationships of number of entrepreneurs and total expenditures. The figure shows matches in most activities. Inequalities are seen in following activities: Professional, scientific and technical activities, Public administration and defense; compulsory social security and education.

Following figure (Figure 4.] shows a comparison between number of entrepreneurs and total investments from the year 2014 to the year 2018. through all activities.

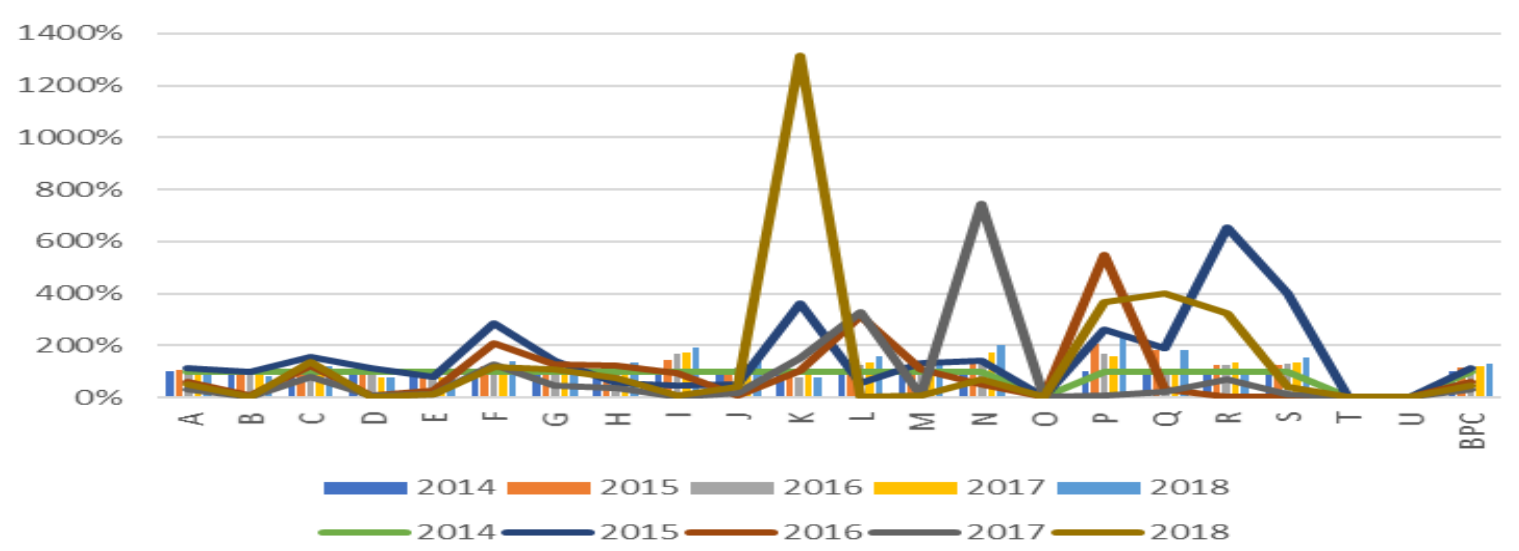

Figure 4. Comparison between number of entrepreneurs and total investments from the year 2014 to the year 2018. through all activities

Source: Authors according to Table 3 and Table 11

The Figure 4. shows changes over the vears in number of entrepreneurs and investments. The figure shows matches in most activities. Inequalities are seen in following activities: Financial and insurance activities, Arts, entertainment and recreation, Administrative and support service activities, Education and Construction. Inequalities in activities in individual years can be linked to contracted projects of EU funds.

\section{Conclusion}

The following can be deduced from the analyzes carried out in the paper:

- $\quad$ The largest number of entrepreneurs are in the following activities: Manufacturing, Construction, Wholesale and retail trade and Professional, scientific and technical activities.

- In 2018, there were 1,842 entrepreneurs, an increase of $8.67 \%$ over the number of entrepreneurs in 2017 and 29\% compared to 2014,
- There were 17,301 employees employed by entrepreneurs, an increase of 12\% compared to the number of employees in 2017, and $29 \%$ compared to 2014,

- $\quad$ In 2018, the revenue from entrepreneurial activity was $18 \%$ higher than in the previous year, and 45\% higher than in 2014,

- In 2018, total expenditures were 20\% higher than in 2017 and $41 \%$ higher than the first year in the observed period,

- Investments were highest in 2015, 146\% higher than in 2018, and 266\% higher than in 2017 when they were smallest. 
Observed data were obtained indirectly from the Croatian Chamber of Economy. In future research, it is possible to take data from a primary survey of business entities and analyze them with additional business indicators. In this way, a broader perception of businesses in Brod-Posavina County could be obtained. Furthermore, the data in this paper were taken to Brod-Posavina County. Future work may take data from a wider area.

\section{References}

[1] Shane, S. \& Venkataraman, S. (2000). The promise of entrepreneurship as a field of research, Academy of Management Review, Vol. 25, №. 1, pp. 217-226.

[2] Wright, M. \& Stigliani, I. [2013]. Entrepreneurship and growth, International small Business Journal, Vol. 31, №. 1, pp. 3-22.

[3] Wong, P. K.; Ho, Y.P. \& Autio, E. [2005]. Entrepreneurship, innovation and economic growth: evidence from GEM data, Small Business Economics, Vol. 24, No. 3, pp. 335-350.

[4] Ahmed, A. \& McQuaid, R. W. [2005]. Entrepreneurship, management, and sustainable development, World Review of Entrepreneurship, Management and Sustainable Development, Vol. 1, No. 1, pp. 6-30.

[5] Baptista, R.; Escária, V. \& Madruga, P. [2008). Entrepreneurship, regional development and job creation: the case of Portugal, Small Business Economics, Vol. 30, No. 1, pp. 49-58.

[6] Tipu, S. A. A. (2012). What have we learned? Themes from the literature on necessity driven entrepreneurship, World Review of
Entrepreneurship, Management and Sustainable Development, Vol. 8, No. 1, pp. 70-91.

[7] Fairlie, R. W. [2013). Entrepreneurship, economic conditions, and the great recession, Journal of Economics \& Management Strategy, Vol. 22, No. 2, pp. 207-231.

[8] Joshi, M. [2010). Fostering innovation: transition from chimps to hyena and lion type innovative enterprise, World Review of Entrepreneurship, Management and Sustainable Development, Vol. 6, Nos. 1-2, pp. 2-16.

[9] Croatian Bureau of Statistics, National classification of the activities 2007 - NKD 2007, https://www.dzs.hr/App/NKD_Browser/assets/do cs/NKD_2007_publikacija.pdf, laccessed 20th February 2020)

[10] Croatian Chamber of Economy: County chamber of Slavonski Brod, Information on the business of the entrepreneur of Brod-posavina county, Reports for 2014th, 2015th, 2016th, 2017th, 2018th year

[11] Financial agency, Business performance results of Brod-posavina county entrepreneurs in 2018, https://www.fina.hr/, laccessed 20th February 2020]

[12] GEM research: Dalmatia, Istria, Primorje and Gorski Kotar show the most intense growth in entrepreneurial activity, http://WwW.novilist.hr/Vijesti/Gospodarstvo/GEM -istrazivanje-Najintenzivniji-rast-poduzetnickeaktivnosti-pokazuju-Dalmacija-Istra-Primorje-iGorski-Kotar (accessed 20th February 2020) [13] European structural and investment funds: https://strukturnifondovi.hr/natjecaji/ [accessed 20th February 2020) 